Política y Sociedad

ISSN-e: 1988-3129

https://dx.doi.org/10.5209/poso.69672

\title{
Determinants of voter participation in Latin American referendums
}

\author{
Matyáš Strnad
}

Recibido: 21-05-2020 // Aceptado: 15-02-2021

\begin{abstract}
Voter turnout in regular parliamentary or presidential elections is a very frequent topic, mainly in the recent debate about its decline. This article works with several theories explaining variations in voter turnout that are subsequently applied on referendums in Latin America. Referendums as one of the main pillars of direct democracy are not, in this regard, sufficiently scientifically explored topic. In this point of view, the region of Latin America is an ideal environment for research of the given subject, because there are many cases of direct democracy applications in the institutional configuration as well as in practice. Voter turnout in referendums is set into a comparative perspective using regression models that allow the researcher to monitor possible correlations and control explaining values. The analysis employs aggregate data from various statistical databases (e. g. V-Dem, Polity IV, World Bank) as well as secondary data from available comparative literature focused on elections (and referendums) in Latin America. The results indicate very high circumstantiality of referendums and the respective societies that apply them in politics. Some institutional settings have been found to positively influence the turnout, mainly compulsory elections.
\end{abstract}

Keywords: referendums; voter turnout; Latin America.

\section{[en] Determinantes de participación electoral en referendos en América Latina}

Resumen. La participación de votantes en las elecciones parlamentarias o presidenciales regulares es un tema muy frecuente, principalmente en el reciente debate sobre su disminución. Este artículo trabaja con varias teorías que explican las variaciones en la participación de los votantes que posteriormente se aplican en los referendos en América Latina. Los referéndums como uno de los pilares principales de la democracia directa no son, a este respecto, un tema suficientemente explorado científicamente. Desde este punto de vista, la región de América Latina es un entorno ideal para la investigación del tema dado, ya que hay muchos casos de aplicaciones de democracia directa tanto en la configuración institucional como en la práctica. La participación de los votantes en los referendos se establece en una perspectiva comparativa utilizando modelos de regresión que permiten al investigador monitorear posibles correlaciones y controlar los valores explicativos. El análisis emplea datos agregados de varias bases de datos estadísticas (por ejemplo, V-Dem, Polity IV, Banco Mundial), así como datos secundarios de literatura comparativa disponible centrada en elecciones (y referendos) en América Latina. Los resultados indican una circunstancia muy alta de los referendos y de las respectivas sociedades que los aplican en la política. Se ha constatado que algunos entornos institucionales influyen positivamente en la participación, principalmente en las elecciones obligatorias.

Palabras clave: referéndums; participación de votantes; América Latina.

Summary. 1. Introduction. 2. Theory. 3. Analysis. 4. Conclusion and discussion. 5. Bibliography.

Agradecimientos. El autor desea agradecer a la Universidad de Hradec Králové por crear un ambiente motivador y amigable de trabajo académico. Especialmente el personal del Departamento de Ciencias Políticas de la Facultad de Filosofía es siempre servicial y abierto a nuevas ideas.

Como citar: Strnad, M. (2022). Determinants of voter participation in Latin American referendums. Polit. Soc. (Madr.) 59(1), 69672. https://dx.doi.org/10.5209/poso.69672

\section{Introduction}

If the beginning of the 20th century was characterized by struggles for suffrage, the 21st century has so far showed a lack of appreciation of that endeavour, symptomatic by declining electoral turnout rates (Pacek, Pop-Eleches, Tucker, 2009; Blais, Rubenson, 2013). Do people simply lose interest in politics and distrust 
democratic institutions' ability to represent their interest? One response to declining popular confidence in democratic institutions is implementing direct democracy institutions (DDIs). Electoral cycles are said to be demotivating for citizens because they cannot decide the shape of their political representation until the next elections (Altman, 2010). The solution is presented by the DDIs, especially those initiated "from below" through which citizens are given another tool for exercising vertical accountability. Although DDIs are more common on local level, from 1980 until 2019, there have been 71 examples of DDI use at national level in Latin America. Referendums and initiatives on national level do not compete in frequency with legislative and executive elections, but in some countries, their use has become a routine in matters of immense importance (e.g., constitutional changes). If we agree that DDIs are relevant elections in Latin American politics, we ought to expect the same conditions as in other tools of democracy. One of these expectations, a debatable one, is that higher voter participation secures better outcomes for society (Lijphart, 1997). Leaving the normative questions aside and focusing on preceding empirical evidence, what causes high or low participation in referendums? Do people participate more in bottom-up initiated referendums? Are some referendums more salient than others? This article identifies the factors for participation in referendums.

There is a vast academic research on determinants of voter participation in legislative and executive elections. DDIs differ from these "typical" elections but explanations of their turnout must stem from this body of literature. Analysts of voter turnout are focused into groups according to what they perceive as the major explanatory variables. These are: institutional perspective (Everson, 1981; Powell, 1982; Jackman, 1987; Lijphart, 1997; Smith, 2001; Rallings et al., 2003; Franklin et al., 2004; Karp and Banducci, 2007; Birch, 2009; Pacek, Pop-Eleches, Tucker, 2009; Lissidini, 2011; Durán-Martínez, 2012; Ruth-Lovell, Welp, Whitehead, 2017; Stockemer, 2017; Kouba, Novák, Strnad 2020), socioeconomical perspective (Radcliff, 1992; Filer, Kenny and Morton, 1993; Aguilar, Pacek, 2000; Nevitte et al., 2009; Carreras and Castañeda, 2016), research of political process (O’Donnell and Schmitter, 1986; Blais, 2000; Kostadinova, Power 2007) and cultural explanations (Almond and Verba, 1963; Inglehart, 1997; Puntam, 2000). Research on voter turnout in referendums is somewhat limited and lacks empirical depth and evidence (Altman, 2010; Durán-Martínez, 2012, Qvortrup, 2014; Renwick, 2017). Detailed analytical works are only available for local level referendums (e.g., Søberg and Tangerås, 2007). A thorough international comparison in the context of Latin American countries has not been added to academic literature yet. This article aims to fill the gap.

This article builds on previous literature and examines determinants of voter turnout in the sense that it gathers relevant variables for the context of DDIs. Comparative perspective on international level can discover some more universal determinants of voter turnout in referendums. But these levels of participation also vary inside the countries. Therefore, in order to achieve a more robust approach, the article builds on time-series cross-sectional generalized least squares models (like those used in Fornos et al., 2004). Nonetheless, the particularity of some instances of DDIs in Latin America requires deeper contextualization. Thus, the methodology is focused on the combination of quantitative and qualitative analysis. The data used are aggregated on national level and correspond with the aims of the article.

A clarification needs to be made before continuing. Direct democracy institution is a category of many electoral tools, some like others and some very distinctive. An exhaustive reflexion on the many forms of DDIs is given by David Altman (2010: 11) and it is based on procedural characteristics of "mechanisms of direct democracy". The distinction is, without a doubt, instrumental in explaining effects of each DDIs. However, for comparison on national level it is overreaching. In this article, the only division in the quantitative analysis is between binding and non-binding DDI, which is included in the model as a dichotomous variable. Both instruments are called referendums; this term is used in describing all the DDIs in the analysis.

Saliency is what determines the outcome of an election (Blais, 2000). In the case of referendums, the argument stays the same. If a public vote (or more precisely the issue in question and the result) is considered a crucial matter, citizens vote in greater numbers (Altman, 2010). Electoral saliency can be constructed in many ways. This article distinguishes several types of referendum in order to uncover the effects of their institutional setting on saliency: binding/non-binding, top-down/bottom-up initiation and concurrent/nonconcurrent.

But the institutional set up of referendums is considered more deeply. Electoral systems are generally very case specific due to the socio-economic and cultural context of countries. But their basic institutional setting is, by virtue of the previous research, quite clear. There are certain provisions we know to influence voter turnout; for example, multipartyism, proportionality of the transition from votes to mandates and district magnitudes (Jackman, 1987). These have little connection to an institution that is becoming increasingly more common in today's politics, DDI. By focusing on comparative analysis, we can find out which institutions function as the most decisive in getting citizens to vote. One very strong institutional proposition revolves around the expectation that citizens will vote in greater numbers in referendums that are initiated by themselves (bottom-up referendums). This expectation has a cultural connection too. The initiation of a bottom-up referendum requires a significant mobilization capability. In a lethargic society, DDIs would hardly gain enough attention. Other control variables are helpful for putting the DDIs in perspective, especially socioeconomical background has proven to be of importance for voter turnout as well. 
Understanding what affects turnout in referendums is beneficial for the judgement of general motivation for participation in elections. And normatively it can lead us to answers about democracy development in Latin America. The push towards a more direct influence on politics is evident. Todd Donovan and Jeffrey A. Karp (2006) examine the reasons for this popular push for direct democracy. On the individual level, interest in politics is a main driving force behind initiations of referendums but the younger generation tends to be more active in this sense (Donovan and Karp, 2006). Even though the question is clear: why do people want more direct democracy? The answer is still elusive. Finding out why they go to polls in these DDIs might reveal an interesting piece of the puzzle.

For the reasons stated above, this article analyses turnout in referendums in Latin America. Following the theoretical framework, that explains some of the chosen variables viable for analysis, multiple regression analysis test is proposed and is complemented by qualitative reasoning for some of the specific cases of DDIs. Only the recent wave of referendums between 1980 and 2019 in Latin America is included in this article.

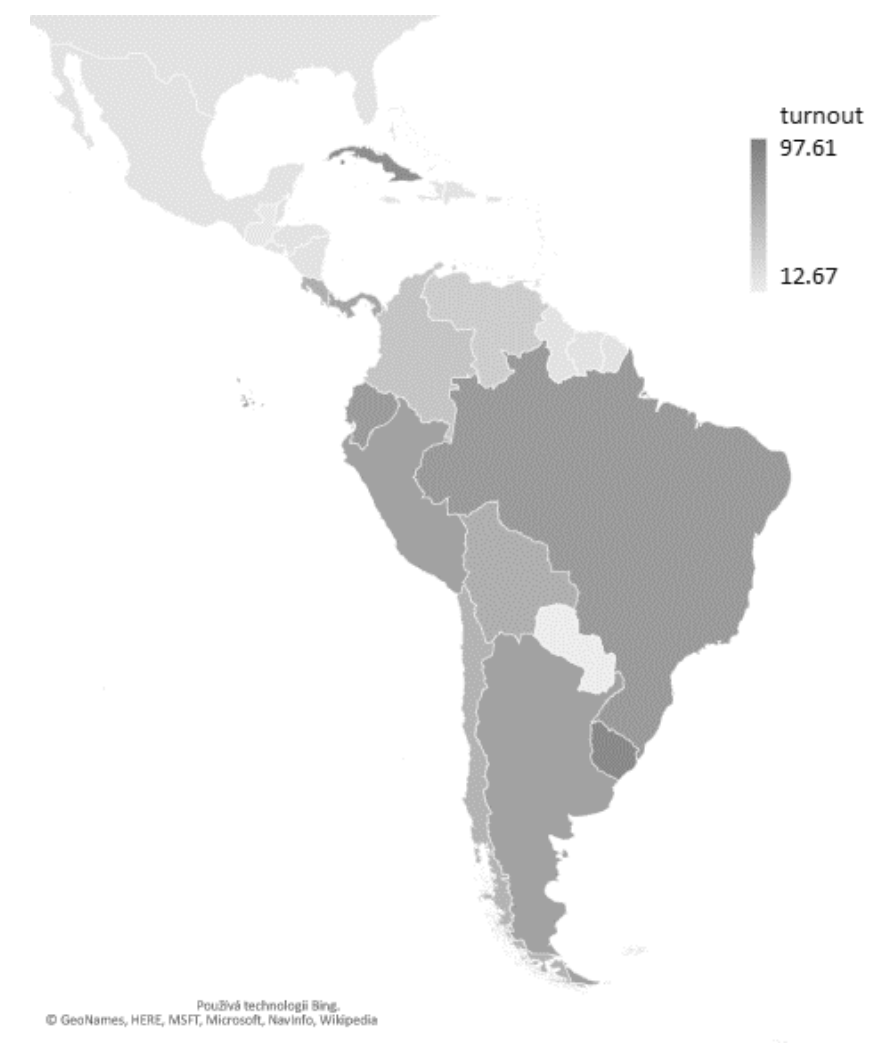

Figure 1. Compiled turnout map

\section{Theory}

The discussion about turnout in thorough comparative perspective in democracies was opened by Powell's (1982) famous book Contemporary Democracies. He states that "nation's social and economic environment, its political institutions and organizations, and the beliefs and strategies of its political leaders help shape political performance" (Powell, 1982: 1). The complexity of politics needs to be put into comparative perspective in order to advance in understanding political reality. In addition, as was established in the introduction, this is still an undiscovered territory of social science in regard of turnout in direct democracy institutions.

Most academic literature is focused on the effect DDIs have on voter turnout in parliamentary or other first order elections. David H. Everson (1981) claims that nations that use some form of DDI do not enjoy higher turnout (Everson, 1981). But this claim was dismissed by Mark A. Smith (2001) who criticized the lack of comparable aspects in Everson's research (Smith, 2001: 701). David Altman studies DDIs in a very profound way, in one of his most cited works, Direct democracy worldwide (2010), he finds out that referendums (in the right conditions) are a positive expression of healthy social activism (Altman, 2010: 29). This must lead to the question: what are the conditions for these institutions to work properly? Functionality (and instrumentality) of referendums (as with any other forms of elections) depends on turnout. A comprehensive work on the functions (their role and effectivity) of referendums in political systems has been published by Saskia P. Ruth-Lovell, Yanina Welp and Laurence A. Whitehead (2017). They do not comparatively analyse turnout, but the conclusion of their research is of essential meaning. "Looking at MDDs (mechanisms of direct democracy) in a broader context, they should be understood largely as a response to growing dissa- 
tisfaction with 'real world' representative institutions" (Ruth-Lovell, Welp and Whitehead, 2017: 218). This explains the academical urge to the investigation of referendums and their turnout.

Salience of a referendum may be influenced by its weight among laws and norms. If a referendum is binding and creates a strong incentive for the elites to accept its result, its relative importance is higher than in a non-binding referendum (Altman, 2010: 18). Empirical evidence for this reasoning is still inconclusive. The results that report zero effect of this variable on turnout might be biased by the difference between formality of a binding referendum and its actual political leverage, which is (as an informal aspect of the issue) very hard to account for (Hobolt, 2009). Altman (2000) also studies bottom-up referendums that are said to be a more effective tool for maintaining vertical accountability of political representation throughout the whole electoral cycle, not just during elections. ${ }^{2}$

Very influential institutional argument develops around concurrent elections. Holding elections simultaneously increases stakes of elections on subjective, individual level (Pacek, Pop-Eleches, Tucker, 2009; Stockemer, 2017). This effect is traceable primarily in joint second order and first order elections $^{3}$. For example, Italian municipal elections enjoy higher turnout when they are concurrent with national legislative elections (Revelli, 2017). And moreover, if less important provincial elections are held simultaneously with more important municipal elections (both are considered second order elections), turnout is increased (Bracco, Revelli, 2018). Causality of concurrent elections and electoral turnout stems from the rational calculus of voters. Most visibly, holding more elections at one time saves time and other resources of voters that are being spent by going to elections. This effect is also yet to be studied in comparative terms of referendums.

It is evident that institutional setting of referendums is vital. One of the strongest pieces of evidence of what affects turnout is given by Sarah Birch (2009). She indicates that repealing compulsory voting had clear negative implications for voter participation in several countries (Birch, 2009: 82-83, 87, 88). The causality stems from the negative motivation that most compulsory voting rules put on voters. This stimulates their calculus of voting. ${ }^{4}$

In broader terms, more general institutional variables influence voting behaviour. Jackman's (1987) analysis proposes another take on voters (de)motivation for elections. He builds on Anthony Downs and theorizes that the more choice (regarding political parties) a voter has the less likely he is to vote. This is because voters in multiparty systems have less control over the actual government negotiation (Jackman, 1987: 408). Even though further inquiry shows some evidence of turnout being higher in two-party systems over multipartyism, the causality of this relationship is not very strong (perhaps because the effect is analysed via proxy). A solution for this might be adding some robustness to methodology. Consider institutionalization of electoral systems, which is one of the components of polyarchy ${ }^{5}$, a certain level of institutionalization is required for the system to work. And as was hinted above, institutionalization of political parties is crucial for elections. However, the link must be approached with caution, especially while studying Latin America (and other regions that Western analysts consider "new democracies"). O'Donnell (1996) specifies that Western standards of institutionalization (and consolidation) need to be revised in order to avoid ambiguity and to be applicable to Latin America (O'Donnell, 1996). In accordance to O'Donnell's recommendations, Jeffrey Karp and Suzan Banducci (2007) found out that party contacts and their closeness (with voters) stimulate mobilization, which then generates higher turnout (Karp and Banducci, 2007: 225-227).

In fact, professionalization of Latin American parties varies across the region. Theory suggests more presence (that allows mobilization) of political parties on national level stimulates turnout, while at the same time too many parties curb it. Even though referendums are a specific type of election, the argument is still relevant because political parties engage in the referendum campaigns (even more so if they played a role in the initiation of a referendum) and their influence is more visible if they are institutionalized (Altman, 2000). Also, political parties work as a horizontal safety check. If they fail to take stands on political issues that are being tackled in referendums, the DDI can easily turn into a powerful tool for authoritative presidents (Durán-Martínez, 2012).

This presents an interesting normative question. Should the politician be controlled that much? Doesn't this create an environment of distrust? One of the most prominent investigators on this issue is Guillermo O'Donnell (e.g., 1996).

For more on the theory of first- and second order elections, see for example Reif, Schmitt and Norris, 1997.

${ }^{4}$ A theory that builds on the suggestion of rational choice of voters. In the calculus $\mathrm{R}=\mathrm{PB}-\mathrm{C}+\mathrm{D}$, where $\mathrm{R}$ is the utility of the vote, $\mathrm{P}$ being the likelihood of presenting the pivotal vote, $\mathrm{B}$ the benefits from the preferred candidate being elected, C represents the costs of voting and D the satisfaction achieved by fulfilling civic duty (Downs, 1957; Riker, Ordeshook, 1968).

5 A concept pioneered by Robert Dahl (1973) defines basic needs for a political system to work democratically: universal, free and fair elections, access to alternative information, freedom of expression, associational autonomy etc. Political systems then can be evaluated according to these criteria and a level of institutionalization is assigned to them (Dahl, 1973). 
Last considered institutional factor refers to the phenomena of electoral fatigue. C. Rallings, M. Thrasher, G. Borisyuk (2003) and M. Franklin et al. (2004) found that having too many elections in a short timespan lowers turnout because voters are simply overwhelmed by the necessity to vote that often (see Rallings et al., 2003; Franklin et al., 2004). A similar conclusion is drawn from the case of Switzerland where referendums are very common (Blais, 2014). The hypothesis is that more frequent usage of referendums shows lower turnout because of voter fatigue.

\subsection{Additional theoretical presumptions}

Already mentioned Guillermo O'Donnell and his colleague Philippe C. Schmitter (1986) presented a very persuasive argument regarding voter turnout. They argued that political processes pose an important contextual variable for electoral results. Specifically transitions to democracy and first elections right after these transitions are said to be pivotal for the political system and further for following elections. If the elites elected in first elections do not fulfil expectations of the electorate, voter's interest in all elections to come is gradually going to diminish (O'Donnell, Schmitter, 1986). Tatiana Kostadinova and Timothy J. Power (2007) advance their rationale by focusing on the type and advance of democratization. They find a connection between historical development and turnout in post-Communist Europe and post-authoritarian Latin America (Kostadinova, Power, 2007). Therefore, an assumption is in place: the level of democracy as well as its age are influential variables for turnout in referendums.

A sizeable group of authors consider turnout to be conditioned by socioeconomic situation of countries. Economy plays a decisive role for Benjamin Radcliff (1992) who claims that the USA are stuck in a perpetual status quo turnout. Middle class, he finds, does not decide to vote according to the economic situation of the country. Economically disadvantaged class, on the other hand, mobilize to overturn the unkind conditions. But economic recession depresses their participation because they simply lack the resources to go to elections (Radcliff, 1992). American families are said to vote more when their income rises (Filer, Kenny and Morton, 1993). A counter argument to Radcliff's, focused on the developing world (Latin America, the Caribbean, Africa and Asia) shows that macroeconomic downturns do mobilize political activism of lower status voters (Aguilar, Pacek, 2000). Miguel Carreras and Néstor Castañeda (2016) adopt a similar approach but their research discovered that "economic downturns only have a mobilizing effect on voters who are in a situation of economic and social vulnerability (in particular people with a low socioeconomic status). On the contrary, economic hardships have a negative (but weaker) impact on electoral participation for citizens who are endowed with more resources" (Carreras, Castañeda, 2016: 20-21). Besides income, other socioeconomical variables have been found to influence turnout. E.g., age, religious attendance and education. Education is specifically connected to better cognitive skills in well-educated populations, which allow citizens enhanced orientation in electoral processes. In addition, citizens with higher levels of education are supposedly more socialized and understand their civic duty more intimately (Nevitte et al., 2009).

The focus so far was aimed at institutional conditions, individual and group motivation. One aspect of political participation tends to be omitted by research. The concept of civic culture is based on premise that modernization broadened people's options for participation but that these changes require corresponding cultural consciousness (Almond, Verba, 1963). Modernization brought new issues into cultural and political consideration. Gradually citizens were given voice that required their interest as well as participation (Inglehart, 1997). Some societies then fare better than others and social capital becomes a requirement for communities of citizens to work well (Putnam, 2000). More social capital leads to higher participation. Corruption on the other hand dampens turnout because it undermines the legitimacy of democratic institutions (Stockemer et al., 2013). Measurements of these hypotheses are included as well.

\section{Analysis}

This analysis comprises Latin American referendums between 1980 and 2019. The upper limit is apparent, the research has been done throughout 2019. The lower one firstly represents the start of the shift (or return) to democratic institutions in many Latin American countries. But it could also be presented as the start of an ongoing growth of DDI use. The highest growth of DDI use was seen during the $90 \mathrm{~s}$, the use of the earlier decades for the sake of broadening the number of cases was deemed acceptable. Table 1 shows all the included examples, 60 in total (some countries excluded because of insufficient data), overall mean is $65.83 \%$. 
Table 1. Turnout in Latin American referendums 1980-2019*

\begin{tabular}{|c|c|c|c|}
\hline Country & Year & Date & Turnout (\%) \\
\hline Argentina & 1984 & $25-\mathrm{Nov}$ & 70.09 \\
\hline Bolivia & 2004 & 18-Jul & 59.9 \\
\hline Bolivia & 2006 & 02-Jul & 84.51 \\
\hline Bolivia & 2008 & 18-Aug & 83.28 \\
\hline Bolivia & 2009 & 25-Jan & 90.24 \\
\hline Bolivia & 2016 & 21-Feb & 84.45 \\
\hline Brazil & 1993 & 21-Apr & 74.24 \\
\hline Brazil & 2005 & 23-Oct & 78.15 \\
\hline Chile & 1980 & 11-Sep & 56.27 \\
\hline Chile & 1988 & 05-Oct & 97.61 \\
\hline Chile & 1989 & 30-Jun & 93.72 \\
\hline Colombia & 1990 & 27-May & 42.37 \\
\hline Colombia & 1990 & 09-Dec & 22.03 \\
\hline Colombia & 2003 & 25-Oct & 26.62 \\
\hline Colombia & 2016 & 02-Oct & 37.43 \\
\hline Colombia & 2018 & 26-Aug & 32.06 \\
\hline Costa Rica & 2007 & 07-Oct & 59.24 \\
\hline Cuba & 2019 & $24-F e b$ & 84.41 \\
\hline Ecuador & 1986 & 02-Jun & 73.56 \\
\hline Ecuador & 1994 & 24-Aug & 64 \\
\hline Ecuador & 1995 & 26-Nov & 58.64 \\
\hline Ecuador & 1997 & 25-May & 59.25 \\
\hline Ecuador & 2006 & 26-Nov & 75.52 \\
\hline Ecuador & 2007 & 15-Apr & 71.31 \\
\hline Ecuador & 2008 & 28-Sep & 75.72 \\
\hline Ecuador & 2011 & 07-May & 77.38 \\
\hline Ecuador & 2017 & 19-Feb & 81.71 \\
\hline Ecuador & 2018 & 04-Feb & 80.73 \\
\hline Guatemala & 1994 & 30-Jan & 15.87 \\
\hline Guatemala & 1999 & 16-May & 18.58 \\
\hline Guatemala & 2018 & 15-Apr & 26.65 \\
\hline Panama & 1983 & NA & 66.75 \\
\hline Panama & 1992 & 15-Nov & 40.06 \\
\hline Panama & 1998 & 30-Aug & 65.41 \\
\hline Panama & 2006 & 22-Oct & 43.32 \\
\hline Paraguay & 2011 & 09-Oct & 12.67 \\
\hline Peru & 1993 & 31-Oct & 70.38 \\
\hline Peru & 2005 & 30-Oct & 87 \\
\hline Peru & 2010 & 03-Oct & 83.53 \\
\hline Peru & 2018 & 09-Dec & 72.53 \\
\hline Uruguay & 1980 & 30-Nov & 86.86 \\
\hline Uruguay & 1989 & 16-Apr & 87.8 \\
\hline Uruguay & 1989 & 26-Nov & 88.67 \\
\hline Uruguay & 1992 & 13-Dec & 82.8 \\
\hline Uruguay & 1994 & 28-Aug & 86.24 \\
\hline Uruguay & 1994 & 27-Nov & 91.5 \\
\hline Uruguay & 1996 & 08-Dec & 85.9 \\
\hline Uruguay & 1999 & 31-Oct & 91.78 \\
\hline Uruguay & 2003 & 07-Dec & 83.4 \\
\hline Uruguay & 2004 & 31-Oct & 89.2 \\
\hline
\end{tabular}




\begin{tabular}{|l|l|l|l|}
\hline Country & Year & Date & Turnout (\%) \\
\hline Uruguay & 2009 & $25-$ Oct & 89.88 \\
\hline Uruguay & 2014 & $26-$ Oct & 90.53 \\
\hline Uruguay & 2019 & $27-$ Oct & 90.14 \\
\hline Venezuela & 1999 & $25-\mathrm{Apr}$ & 36.31 \\
\hline Venezuela & 1999 & $15-\mathrm{Dec}$ & 44.05 \\
\hline Venezuela & 2000 & $03-\mathrm{Dec}$ & 22.34 \\
\hline Venezuela & 2004 & $15-\mathrm{Aug}$ & 69.92 \\
\hline Venezuela & 2007 & $02-\mathrm{Dec}$ & 56.15 \\
\hline Venezuela & 2009 & $15-\mathrm{Feb}$ & 70.33 \\
\hline Venezuela & 2017 & $16-\mathrm{Jul}$ & 37 \\
\hline
\end{tabular}

Source: electoral institutes of particular countries supplemented by Nohlen 2005a, 2005b.

* Missing data for some countries ruled them out of the dataset. These countries are Antigua and Barbuda, Bahamas, Belize, Grenada, Haiti and St. Vincent and the Grenadines.

\subsection{Qualitative outlook}

As it will be clear from the quantitative study later, some of the results from the specified models show a counter intuitional implication. An introduction to some of the specific cases is in place. Even though the focused geographical demarcation ensures some homogeneity in the reference frame, the group of countries in the analysis and their contextual setting undoubtedly changed throughout the years. Therefore, the following reference to the specifics of the cases.

One variable that has been omitted from the quantitative frame is the topic of a referendum. The reason for that is the intricate data gathering and their link with other variables, especially the dependent one. As is stated in the appendix of Figure 3, Altman (2014) operationalizes this issue by counting each question in referendums as a separate topic. Some cases of DDIs, e.g., Ecuador in 2018, presented 7 ballot questions, some of which could fall into more than one category. ${ }^{6}$

Figure 2. Rreferendum topics

DDI topics (1978-2019)

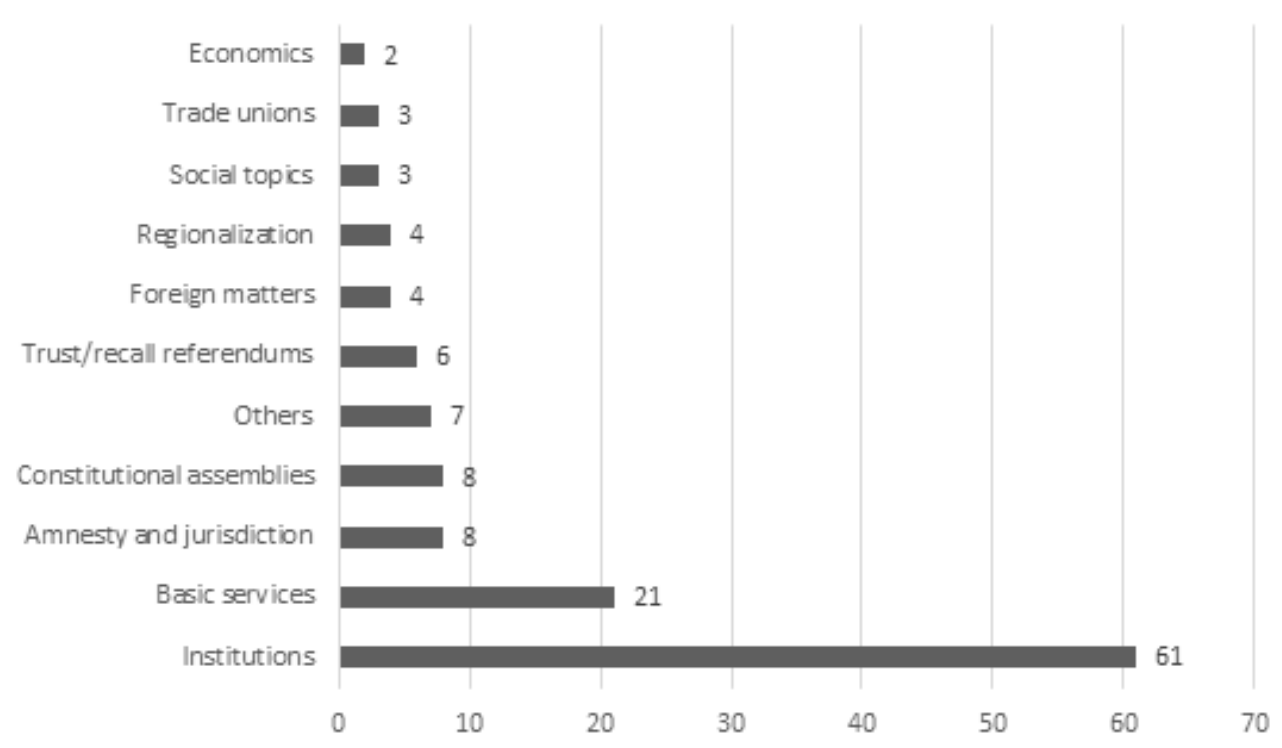

Source: data 1978-2011 Altman, 2014: 178; data 2012-2019 electoral institutes. Altman (2014) counts each particular question as a separate topic, that is why there are a lot more topics than actual referendum cases.

${ }_{6} \quad$ For example, the question: "Do you agree to amend the Constitution of the Republic of Ecuador to prohibit metallic mining in all its stages, in protected areas, in intangible zones, and urban centers, according to Annex 5?" could be assigned to institutions, because it asks about a constitution amendment; economics, because it would influence the mining sector; or basic services, because it refers to housing and urban zones. 


\subsubsection{Double referendums}

A special case is presented by so called "double referendums". In normal circumstances, these are considered as separate elections but since they were called for the same day, they are treated as just one case. Bolivian double referendum in 2009 deserves more attention. The referendum was not concurrent with any parliamentary or presidential elections, but the two questions presented arguably a very salient topic - new constitution and land reform (Santos Villarreal, 2009). The new constitution severely altered the institutional setting of the country? The two referendums saw the highest turnout out of all the Bolivian referendums, $90.24 \%$ and $90.14 \%$; the difference from the other ones being around $6 \%$ points. In this case, variables measuring diverse democratic performance (free political competition, institutionalization of political parties, additive polyarchy index and democracy development) were higher than in the last case from 2016. With one exception of corruption, which rose from -0.55 to -0.02 . Presumably, corruption was not hindering turnout for Bolivia, more instrumental was the topic (constitution) and concurrence.

Another example is Colombia in 1990. The referendum in May was preceded by an unofficial referendum initiated by students in March. Topic that dominated the unofficial referendum was the critical political situation and security (Torres Forero, 2006). Turnout in the first referendum in May was $42.37 \%$, only about 100 000 more voters participated in concurrent presidential elections (Nohlen, 2005b: 317). The following referendum called by recently elected president César Gaviria had seen essentially the same question as the previous one. It asked if the Constituent Assembly should be elected. Those who voted yes could then proceed to vote for the composition of the assembly. This complexity in combination with electoral fatigue (Colombians voted for the sixth times that year) ${ }^{8}$ might have contributed to low electoral participation of only $22.03 \%$.

In Uruguay general elections often present additional question in type of a DDI for the voters. In years, 1994, 1999 and 2009 general elections related to a double referendum. Uruguayan constitution counts with a popular ratification for any legislature that amends or changes the constitution itself (Ruth-Lovell, Welp, Whitehead, 2017: 25), thus, in November 1989, August 1994, 1996, 2004, 2014 and 2019 Uruguayans went to polls to vote for or against various constitutional reforms. All variables that measure different democracy institutions correlate positively with Uruguay's high turnout rates. Moreover, while Uruguay is being compared to Switzerland (see e.g., Ruth-Lovell, Welp, Whitehead, 2017), no voter fatigue seems to be present. On the contrary, Model 1 shows positive influence of the frequency of DDIs use on voter turnout. Referendum that saw the highest turnout (91.78\%) was the one from 1999. Apart from being double and concurrent with general elections, it was not special in any other aspect. The two topics presented were judicial financial autonomy and the possibility for directors of state-owned companies to run for office as members of the legislative body. The voters rejected both questions. While the case cannot show us any substantial leads to the causal relationship, we must adhere to explanations that are more general.

The Bolivarian Republic of Venezuela is one of the countries (others are Uruguay, Ecuador and possibly Colombia) where referendums are not uncommon. All together 7 referendum cases were observed in the analysis. Although there were no concurrent referendums in Venezuela, in 1999 Venezuelans voted twice in two referendums, one in April and one in December. Neither of which were concurrent with any other type of election. Both were constitutional, both called by President Chávez. Their turnout was $36.31 \%$ and $44.05 \%$ respectively. With the average turnout in referendums for the country of $48.01 \%$, Venezuela places at 4 th lowest turnout in the examined countries. All Venezuelan referendums were initiated from above, with the 2004 referendum being initiated by opposition's petition and the 2017 by Venezuela's National Assembly. The 2004 referendum had the second highest turnout (69.92\%), by a small margin of $0.4 \%$, referendum from 2009 was the first with the highest participation. There was no institutional change in Venezuela between these two elections. The only dramatic change is visible in democracy development, where Venezuela dropped from 6 to -3 (Pemstein et al., 2018). Referendum from 2009 was of a high profile because it asked the people if they agree with removing the term limits for president's office (and other offices). ${ }^{9}$

\subsubsection{Outliers}

There are extreme cases in the dataset. One is represented by Paraguay. Only one case of referendum is present in the analysis and one that saw the lowest turnout in the dataset. There were three referendums in the history of Paraguay. One after the war against Bolivia in 1938 and the other that did not pass the time threshold of this research happened in 1940 (Nohlen, 2005b: 425). The one referendum from Paraguay's modern democratic history was in 2011. Its turnout being only $12.67 \%$. Elections in Paraguay are compulsory, but the institution is not enforced by any means. The referendum passed with $77.5 \%$ of voters in favour. President Lugo succeed

The project of Evo Morales was of crucial importance to Bolivia. New constitution set out to draft the rules for recognition of the many minorities that exist in Bolivia (Santos Villarreal, 2009: 1).

8 Which would support the thesis presented by Rallings et al., 2003 and Franklin et al., 2004.

For more about the question of term limits removal see Kouba, 2016. 
in convincing the Paraguayan voters and the presented issue: expat citizens ability to vote, was accepted. But using the ability did not prove to be very popular among Paraguayans. This might be caused by the broad consensus that already existed on the issue. Paraguay's two-chamber legislature passed this constitutional amendment without any hindrance, the Senate voted even unanimously (Palop-García, Pedroza, 2019: 412413). Even though the overall conditions of Paraguay (even regular elections enjoy a stable turnout) when we consider referendums are comparatively enough, Paraguayans are just not used to this institution of direct democracy.

One country that is not considered democratic even in recent years is Cuba (Polity IV, 2018).${ }^{10}$ Cuba's 2019 referendum is (among the analysed cases) a queer example. Apart from literacy, no other presupposed beneficial condition for higher turnout was met. Yet it showed one of the highest turnouts in the reference group, $84.41 \%$. There is no compulsory voting, it scores low on the measures of democracy, civil society is quite passive (score of -1.1 suggests no public deliberation of policies and even discouragement from public discussion of political topics) and its corruption high ( -1.0 score). The voters decided on the newly drafted constitution. Some observers of the 2019 referendum were sceptical about the whole process, even though they admit that the constitution itself is contributing to better protection of human rights (e.g., Rivero, 2019). There is a sound theory that could explain modus vivendi of Cuban political development. It assumes that liberal democracies seized democratic theory and are not accepting any revisions. But these revisions exist and are presented on the example of Cuban popular democracy (evaluated as an authoritarian regime by the operationalization of polyarchy), in which the Western liberal concepts fail (Baker, Sapio, 2019). This could also explain the high turnout because the model (based primarily on Western measures) is failing to do so.

Another example of an authoritarian regime that fares well in terms of turnout in referendums is Chile in 1980s. Additive polyarchy index comprises evaluation of institutionalization of political system and its political parties. But speaking about institutionalization of political system and its parties in the case of Chile is more problematic. Especially in the 1980s. The military regime crafted serious barriers to political parties, particularly on the left. In 1987 new legislation regarding registration of political parties came into force. This provision restricted Marxist groups to register as political parties, so a series of "instrumental" names in a round of attempts for registration were invented - although not only by Marxist groups (Valenzuela, 1995: 52). The opposition only came together as a united force in the 1988 referendum, in which they created a strong campaign for "No" (to the continuation of Augusto Pinochet). The informal cohesion of opposition in the process created a very strong appeal to citizens to vote. The campaign underlined salinity of these two referendums (an argument that fits into the theory created by LeDuc, 2007).

\subsection{Quantitative study}

The dependent variable in this research is electoral turnout in referendums measured as the share of voters in the total registered citizens for elections.

A set of independent variables is constructed based on the previous theory. Most of the data for variables were collected from V-Dem project (Coppedge et al., 2019a). Compulsory election is operationalized as an ordinal scale of 0 to 3 , while 0 is no obligation for citizens to vote and 3 existing compulsion with strict and severe sanctions for violators (Coppedge et al., 2019b: 69). This allows to differentiate between the various effects on turnout in countries that have distinctive compulsory election laws. The expected direction of causality is that more rigid compulsory elections cause higher voter turnout.

Free political competition as a predisposition to multipartyism is computed on indicator called barriers to parties (Coppedge et al., 2019b: 87). It is measured as an interval with a scale of 0 to 4 , while 0 represents prohibition of political parties and 4 no barriers to parties whatsoever. This variable on itself would not provide a sufficient connection with turnout, so as was mentioned above, it is complemented by another measure. Institutionalization of political parties regulates the expectations. Operationalization of this variable is based on the number of national-level parties that possess permanent organizations. Interval starts with 0 stating that no party has permanent organization on the national level and ends with 4, all parties in the system have permanent organizations (Coppedge et al., 2019b: 89). Thus, the expected effect is conditioned: if the two variables correlate, their effect on turnout is positive.

General institutional conditions for higher turnout are expressed as V-Dem's additive polyarchy index. The index is ordinal, and its 5 categories version comprises 0.00 evaluated as closed autocratic system, 0.25 autocratic system, 0.50 ambivalent, 0.75 minimally democratic system and 1.00 democratic (Coppedge et al., 2019b: 300). Assuming that more democratic systems produce higher turnouts.

The effect of concurrent elections is measured on a dummy variable, which was assembled by the author's own work. If a referendum happened on the same day as any other election, the case was assigned a 1, if not 0 . A positive correlation is expected.

10 For an alternative opinion, see for example García, 2019. 
Objective saliency of referendums is operationalized via two dummy variables. Binding/non-binding: referendums were given 1 in cases where their results were obligatory for the political elites to implement; non-binding referendums were given 0 . A positive effect is expected. The second dummy, bottom-up/top-down initiation, gives 1 to referendums that were initiated by the citizens (bottom-up) and 0 if they were initiated by any other actor (usually executive or legislative political leaders). Theory suggests a positive correlation of this variable with the dependent one.

Another independent variable in the institutional section operationalizes voter fatigue. The measurement is based on V-Dem's direct popular vote index. The ordinal scale ranges from 0 (no or very little use of DDIs) to 1 (DDIs are a frequent tool in politics) (Coppedge et al., 2019b: 311).

Because some of the examples included in the dataset do not represent democratic systems, a dummy variable that differentiates the two types. Authoritarian regimes (falling below 0 in the Polity IV index) were given 1, all other systems gained 0 .

A group of control variables is introduced into the model to ensure robustness. First group is dedicated to broad political processes. Literature suggests that turnout is going to be higher in countries in which democracy development was more successful. This suggestion is controlled for by implementing two variables. First, levels of democracy evaluated by Polity IV project scale countries by 10 (strong democracy) to -10 (strong autocracy) (Polity IV, 2019: 16). This measurement is complemented by author's own calculations of the age of democratic system in all included cases. Here supposing older democracies with higher levels of democracy returning higher turnouts.

Second group comprises three socioeconomical and demographical variables for which literature reports the most influence on voter turnout. Economic conditions are operationalized on a numerical variable of GDP per capita for each case. Data were collected from World Bank dataset (World Bank, 2019). Empirical evidence showed that the causal mechanism might work both ways. However, most literature advocates for the positive effect of enriching population on voter turnout. To control for any inconsistencies, another connected variable was incorporated. Inequality is measured by V-Dem's equal distribution of resources index (Coppedge et al., 2019b: 312), ordinal scale ranges from 0 to 1 . Higher numbers indicate more equal distribution of resources. Last variable in this group is literacy. Literacy is simply calculated as the average years of education among citizens older than 15 (Coppedge et al., 2019b: 323). Societies that are more educated participate in election more often.

The third group of variables controls for cultural specifics of the analysed cases. A measurement of engaged civil society is based on an interval scale of public deliberation. It ranges from 0 (public deliberation never happens), to 5 (whole society is engaged in deliberation) (Coppedge et al., 2019b: 149). Expected direction of causality is that more engaged societies will participate in elections in higher numbers. Second variable in this group measures corruption. Interval scale focused on routinely exchanged favours for material inducements in public sector ranges between 0 (bribery is extremely common) and 4 (corruption is not present) (Coppedge et al., 2019b: 120). More corruption causes distrust in democratic institutions and leads to lower turnouts in elections.

Table 2. Descriptive statistics

\begin{tabular}{|l|l|l|l|l|l|l|}
\hline Variable & Coding & Obs & Mean & Std. Dev. & Min & Max \\
\hline Turnout & turnout & 60 & 66.34 & 23.64 & 12.67 & 97.61 \\
\hline Compulsory elections & CompE & 60 & 1.63 & 1.18 & 0.00 & 3.00 \\
\hline Free political competition & FreePC & 60 & 1.41 & 1.05 & -2.44 & 2.78 \\
\hline $\begin{array}{l}\text { Institutionalization of political } \\
\text { parties }\end{array}$ & InstitutPP & 60 & 1.27 & 0.77 & -0.31 & 2.90 \\
\hline Additive polyarchy index & Poly & 60 & 0.87 & 0.25 & 0.00 & 1.00 \\
\hline Concurrent elections & Conc & 60 & 0.23 & 0.43 & 0.00 & 1.00 \\
\hline Binding/non-binding & refType & 60 & 0.95 & 0.22 & 0.00 & 1.00 \\
\hline Bottom-up/top-down initiation & CI_ref & 60 & 0.17 & 0.38 & 0.00 & 1.00 \\
\hline Voter fatigue & DDIuse & 60 & 0.31 & 0.19 & 0.02 & 0.69 \\
\hline Authoritarian system & Authoritarian & 60 & 0.12 & 0.32 & 0.00 & 1.00 \\
\hline Democracy development & DemLev & 60 & 6.42 & 4.44 & -7.00 & 10.00 \\
\hline Age of democratic system & YearDem & 60 & 14.38 & 13.57 & 0.00 & 58.00 \\
\hline GDP per capita & GDP & 60 & 10574.92 & 4038.61 & 4524.00 & 21016.00 \\
\hline Inequality & Inequality & 60 & 0.55 & 0.21 & 0.16 & 0.90 \\
\hline Literacy & Literacy & 60 & 7.67 & 1.07 & 4.37 & 10.28 \\
\hline Civil society engagement & CivSoc & 60 & 1.27 & 1.29 & -2.17 & 3.15 \\
\hline Corruption & Corruption & 60 & 0.04 & 1.07 & -2.47 & 1.57 \\
\hline
\end{tabular}


Data were collected for all 60 cases of Latin American referendums on national level in years 1980-2019 (Table 2). Some countries had to be excluded from the analysis due to lack of reliable resources of data. Data were organized based on TSCS (time-series cross-sectional) methodology, which allows comparison between included countries as well as in time (where there were more referendums throughout the years) (Podestà, 2002: 16). After correlation tests, compulsory elections and literacy showed the highest correlations, 0.79 and 0.70 , respectively. Because TSCS data violate classical OLS (ordinary least squares) regression conditions of homoscedasticity and uncorrelated error terms, two complex GLS (generalized least squares) models were designed with a series of tests for statistical significance. One generalized linear mixed model with penalized quasi likelihood that deals with non-normal data also served as an additional test and even though is not reported (the different mathematical approach lists incomparable estimates), its p-values agreed with the previous results.

\subsubsection{Statistical models}

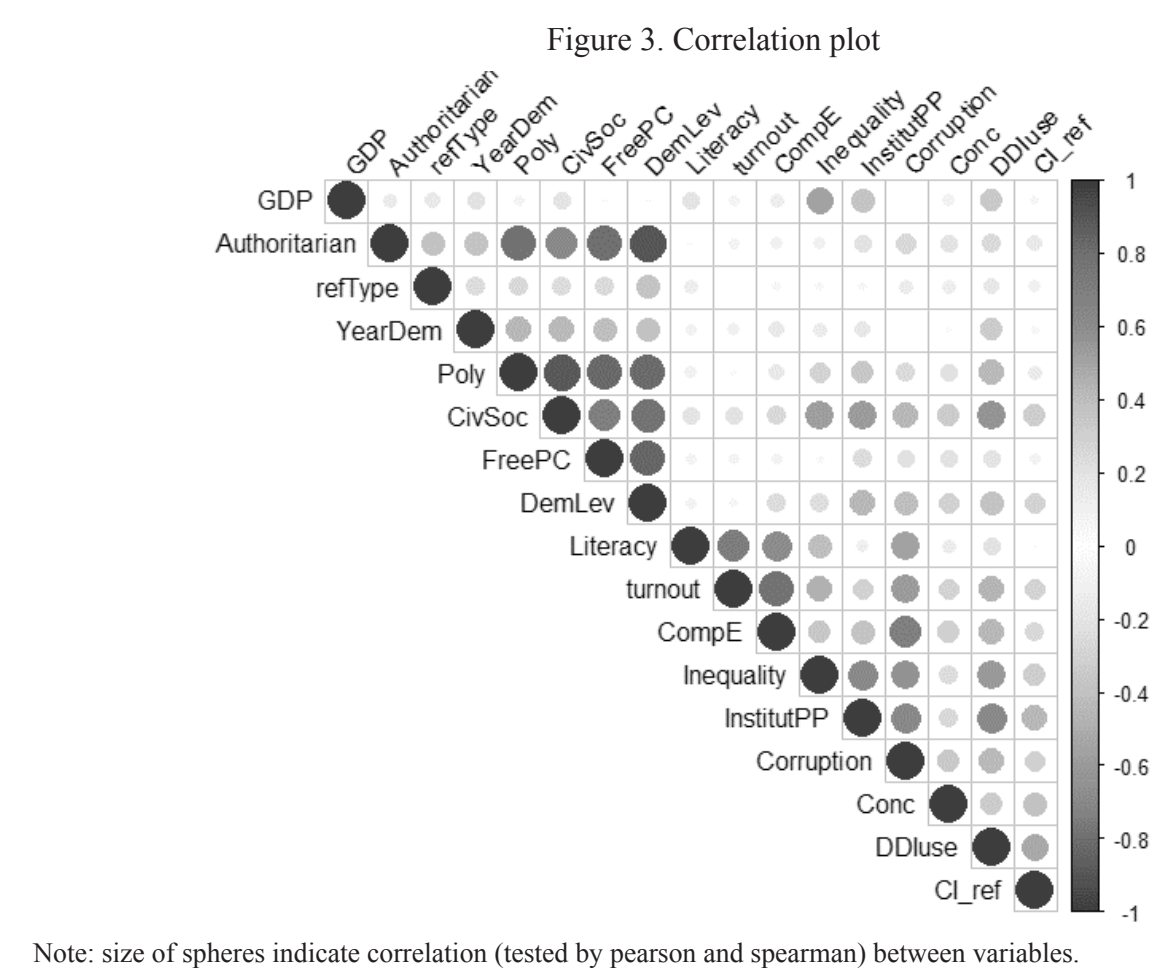

The correlation plot (Figure 3) shows that some variables are intercorrelated and their influence might be biased. Thus, two regression models are estimated. One including all mentioned variables and, in order to prevent multicollinearity, one excluding the three most intercorrelated - free political competition, democracy development and civil society engagement. Models display similarities but also very interesting differences.

At first sight, the models report a very high estimates for some of the variables. Compulsory elections estimate $^{11}$ in Model 1 is 10.81 and in Model 2 11.68, which is very satisfying for advocates of this institutional provision for higher turnout. The scale also provides a reason to argue for stricter compulsory elections rules. The second variable with high significance is literacy. The prediction here is also in accordance with the test results with estimates for Model 1 and Model 2, 10.64 and 9.43 respectively.

Model 1 than reports a surprising direction and size of the coefficient of additive polyarchy index. Interpretation of the estimate $(b=-36.53)$ is that more authoritative states enjoy higher turnout rates in referendums (the variable loses statistical significance in Model 2). Authoritarian systems report similarly quite high estimates, but their statistical significance fails.

11 Estimates of coefficients signify the change in the dependent variable for each point of change in the independent variable. In this context, the numbers are percentage points of turnout surplus (or decline). 
Table 3. Regression Models, parameter estimates for Latin American referendums turnout from 1980-2019

\begin{tabular}{|l|l|l|l|l|}
\cline { 2 - 5 } \multicolumn{2}{|c|}{} & \multicolumn{2}{c|}{ Model 1 } & \multicolumn{2}{c|}{ Model 2 } \\
\hline Variable & \multicolumn{1}{|c|}{ b } & \multicolumn{1}{c|}{ b } & \multicolumn{1}{c|}{ t } \\
\hline Intercept & 15.08 & -0.69 & -27.87 & -1.48 \\
\hline Institutional variables & & & & \\
\hline Compulsory elections & 10.81 & $4.33^{* * *}$ & 11.68 & $4.18^{* * *}$ \\
\hline Free political competition & 6.35 & $1.79^{*}$ & & \\
\hline Institutionalization of political parties & 0.59 & 0.15 & 0.82 & 0.20 \\
\hline Additive polyarchy index & -36.53 & $-2.10^{* *}$ & -11.00 & -1.02 \\
\hline Concurrent elections & 3.84 & 1.10 & 5.32 & 1.46 \\
\hline Binding/non-binding & -6.47 & -0.83 & -4.96 & -0.62 \\
\hline Bottom-up/top-down initiation & 5.60 & 1.33 & 5.41 & 1.26 \\
\hline Voter fatigue & 22.65 & 1.57 & 6.84 & 0.45 \\
\hline Authoritarian system & 12.00 & 0.98 & 5.18 & 0.61 \\
\hline Political processes variables & & & & \\
\hline Democracy development & -1.01 & -0.88 & & \\
\hline Age of democratic system & 0.25 & $1.68^{*}$ & 0.21 & 1.33 \\
\hline Socio-economic variables & & & & \\
\hline GDP per capita & 0.00 & $-1.80^{*}$ & 0.00 & -1.19 \\
\hline Inequality & 17.99 & 1.33 & 31.82 & $2.54 * *$ \\
\hline Literacy & 10.64 & $4.26^{* * *}$ & 9.43 & $3.70^{* * *}$ \\
\hline Civil society engagement & & & & \\
\hline Corruption & 4.19 & 1.28 & & \\
\hline$n$ & -5.58 & $-1.76^{*}$ & -5.37 & -1.58 \\
\hline Cultural variables & & 60 & & 60 \\
\hline
\end{tabular}

$* \mathrm{p}<0.1, * * \mathrm{p}<0.05, * * * \mathrm{p}<0.01$

There are four other variables with significant statistical value in Model 1. Free political competition $(b=6.35)$ should relate to institutionalization of political parties, but this variable has not proven significant. Nonetheless this variable was dropped out from Model 2 (due to collinearity). Age of democratic system is estimate is very small (0.25) and similarly to GDP per capita and corruption measurements, it does not show enough constancy (see Model 2). Corruption estimate $(b=-5.58)$ suggests lower turnout in countries with less corruption.

Lastly, Model 2 reports a serious rise in inequality estimates (from $b=17.99$ to $b=31.82$ ), which is also connected with statistical significance. The variable is one of the three socio-economic ones included in the model and it might seem that there is a collinearity issue, but variance inflation factor (VIF) did not reveal any problems. Therefore, societies with less discrimination enjoy higher participation in referendums. Homogenous societies fair better in mobilizing political support for issues of great importance, often represented at referendum ballots.

The models also note some interesting implications of variables that were expected to have a major influence on turnout in referendums. None of the salience measurement gained statistical significance. This might be the cause of the operationalization; binary measurement is not the most effective for uncovering causality. And even though voter fatigue did not reach statistical significance either, its estimates $(b=22.65$ and $b=6.84)$ do not suggest, that citizens are tired of going to the polls if they are asked to vote too often. On the contrary.

\section{Conclusion and discussion}

Reviewed literature suggests several implications for voter turnout (applied to referendums). Alan Renwick (2017) in his compilation of previous research makes speculations on the turnout determinants in referendums. He seemingly puts representative and direct democracy in opposition to one another and points out some possible influential variables - salience of the issue at hand; two institutional variables, one of which is the authority of the initiation of referendums; and the second one being the effect of binding and non-binding referendums (Renwick, 2017: 4-7). Renwick's conclusions are in accordance with the findings presented here, popular-initiated referendums do not attract more voters than referendums initiated from above. Renwick also considers the demographic specifications of voters in referendums, nonetheless, the empirical evidence in his article is very sparse. Salience of issues that are being presented to voters in referendums is a bearing topic in 
the discussion. ${ }^{12}$ However, before examining these highly atomized influences, there ought to be a debate on the institutional and other contextual settings for referendums.

The quantitative analysis revealed that there are some influential variables that are common to regular elections and referendums. Two most prominent predictors of turnout in referendums are compulsory elections and literacy. The argument for compulsory participation in elections (Birch, 2009) again proves its validity. Exceptions exist (Cuban referendum had one of the highest turnouts, but the vote was not mandatory) yet the statistical test shows that overall, mandatory elections positively affect turnout. Literacy as a control variable showed that its role in creating incentives for voting is far from negligible. Even though literacy grows in time, the same thing cannot be said about turnout in referendums. So, the variable is informative but cannot be considered as a clear explanation of causality.

Polyarchy is statistically significant explanatory variable in the first model. The direction of the estimates is surprisingly (at least from the theoretical perspective) negative. The inclusion of non-democratic cases like Chile (in the time of referendums) and Cuba, which saw high levels of turnout, might have shifted the magnitude of the estimates by a considerable amount. At the same time, Latin American countries might have found a way to avoid the demands for prototype democracies and still be able to ensure citizens participation in politics. This would support arguments presented by Guillermo O'Donnell (1996).

Concurrent elections showed some influence only at the national level in the case of Uruguay. Referendums are gaining more space in politics (especially in Latin America), they either already are or are being implemented into many political systems. ${ }^{13}$ They are still not as regular as legislative or presidential elections, and they tend to appear only when there is a push for a certain topic to be discussed more broadly. Regularity of legislative and executive elections stems from the notion of accountability of political representation. The debate over accountability (and lack of the traditional one in Latin America) has gained some momentum (e.g., Breuer, 2007). DDIs might represent a threat to vertical accountability but the evidence from Uruguay shows that they can serve as a valuable add to deliberation of public agendas when used at the same time as general elections.

The measurement of salience in this article refers to referendums as binding, which are in theory more salient, and non-binding, which are less salient (Altman, 2010). Statistical test did not prove this an important aspect for turnout. Another possible proxy for salience is the initiation of a referendum. Again, this is not the case and bottom-up referendums do not ensure higher turnout. However, as was mentioned above, salience has many interpretations and its importance for turnout needs to be submitted to further testing.

Voter fatigue did not show any influence. Theory suggested that voters would participate less with the growing number of elections calls in a short timespan (Rallings et al., 2003; Franklin et al., 2004; Blais, 2014). In the presented analysis, this was not proven. On the contrary, if you consider the presented estimates, going to referendums more often increases the overall participation. The results in this point derive from the effect of Uruguay, where national referendums are very common, and they are highly participative.

Some of the non-institutional variables showed influence. Corruption in this analysis did not dampen turnout. Higher levels of the index of corruption means that there is less corruption in a country. Negative coefficients for corruption in turnout then suggest that less corrupt countries have less turnout in referendums. One possible explanation suggests that the matter of whether corruption dampens or supports turnout lies in individuals' employment sector (Haveric et al., 2018). Perception of corruption is a very subjective topic, so a comparative analysis on national level probably cannot reveal much.

Examining the topic showed some promising breakthrough in our perception of voter participation in referendums. Comparing different countries in this context is not only feasible but also conducive. Institutional setting plays a major role in determining the actual voter participation and some non-institutional influences were revealed as well. This first stage of the investigation on the topic has shown that there is potential in its methodological structure and further research is highly recommended.

\section{Bibliography}

Aguilar, E. E. and A. C. Pacek (2000): "Macroeconomic conditions, voter turnout, and the working-class/economically disadvantaged party vote in developing countries", Comparative Political Studies, 33(8), pp. 995-1017.

Almond, G. A. and S. Verba (1989): The civic culture: political attitudes and democracy in five nations. [New ed.], Newbury Park, Calif., Sage Publications.

Altman, D. (2010): Direct democracy worldwide, Cambridge University Press.

Altman, D. (2014): "Direct democracy in Latin America", in M. Qvortrup, Referendums around the world: the continued growth of direct democracy, Houndmills, Basingstoke, Hampshire: Palgrave Macmillan.

12 As was shown in the example of Chile. A great introduction to the topic provides Lawrence LeDuc (2007). He proposes one measure of salinity of referendums - campaign intensity. Campaigns without a doubt highlight the importance of an election. But there is not enough empirical evidence that this is not the case only for elections that are already perceived as salient.

13 For a comparison, see Ruth-Lovell, Welp and Whitehead, 2017. 
Backer, L. C. and F. Sapio (2019): "Popular Consultation and Referendum in the Making of Cuban Socialist Democracy 2.0 Through the Lens of Cuba's 2019 Constitutional Reform Project”, University of Miami International \& Comparative Law Review, 27(1), pp. 37-130.

Birch, S. (2009): Full participation: a comparative study of compulsory voting, New York, United Nations University Press.

Blais, A. (2000):To vote or not to vote?: The merits and limits of rational choice theory, University of Pittsburgh Pre.

Blais, A. and D. Rubenson (2013): “The source of turnout decline: New values or new contexts?”, Comparative Political Studies, 46(1), pp. 95-117.

Blais, A. (2014): "Why is turnout so low in Switzerland? Comparing the attitudes of Swiss and German citizens towards electoral democracy", Swiss Political Science Review, 20(4), pp. 520-528.

Bracco, E. and F. Revelli (2018): "Concurrent elections and political accountability: Evidence from Italian local elections", Journal of Economic Behavior \& Organization, 148, pp. 135-149.

Breuer, A. (2007): "Institutions of direct democracy and accountability in Latin America's presidential democracies", Democratization, 14(4), pp. 554-579.

Cámara Nacional Electoral (2019): Ciudad Autónoma de Buenos Aires: Cámara Nacional Electoral. Available at: https://www. electoral.gov.ar/ [Accessed: 15. 12. 2019]

Carreras, M. and N. Castañeda (2016): "Economic Adversity and Voter Turnout: A Multilevel Analysis", Working paper, International Political Science Association.

Consejo Nacional Electoral (2019): Bogotá: Consejo Nacional Electoral. Available at: http://www.cne.gov.co/ [Accessed: 7.12. 2019]

Consejo Nacional Electoral (2019): Caracas: Consejo Nacional Electoral. Available at: http://www.cne.gov.ve/web/index.php [Accessed: 15. 12.2019]

Consejo Nacional Electoral (2019): Quito: Consejo Nacional Electoral. Available at: http://cne.gob.ec/es/ [Accessed: 8. 12. 2019]

Coppedge, M., J. Gerring, C. H. Knutsen, S. I. Lindberg, J. Teorell, D. Altman, M. Bernhard, S. Fish, A. Glynn, A. Hicken, A. Lührmann, K. L. Marquardt, K. McMann, P. Paxton, D. Pemstein, B. Seim, R. Sigman, S-E. Skaaning, J. Staton, S. Wilson, A. Cornell, L. Gastaldi, H. Gjerløw, N. Ilchenko, J. Krusell, L. Maxwell, V. Mechkova, J. Medzihorsky, J. Pernes, J. von Römer, N. Stepanova, A. Sundström, E. Tzelgov, Y. Wang, T. Wig and D. Ziblatt (2019): V-Dem [Country-Year/CountryDate] Codebook v9, Varieties of Democracy (V-Dem) Project. Available at: https://doi.org/10.23696/vdemcy19 [Accessed: 7. 12. 2019]

Corte Electoral (2019): Montevideo: Corte Electoral. Available at: http://www.corteelectoral.gub.uy/ [Accessed: 8. 12. 2019]

Dahl, R. A. (1973): Polyarchy: Participation and opposition, Yale University Press.

Donovan, T. and J. A. Karp (2006): "Popular support for direct democracy", Party politics, 12(5), pp. 671-688.

Downs, A. (1957): An Economic Theory of Democracy, New York, Harper.

Durán-Martínez, A. (2012): "Presidents, parties, and referenda in Latin America",Comparative Political Studies,45(9), pp. 11591187.

Everson, D. H. (1981): “The Effects of Initiatives on Voter Turnout: a Comparative State Analysis”, Political Research Quarterly, 34 (3), pp. 415-425.

Filer, J. E., L. W. Kenny and R. B. Morton (1993): "Redistribution, income, and voting”, American Journal of Political Science, 37, pp. 63-87.

Fornos, C. A., T. J. Power and J. C. Garand (2004): "Explaining voter turnout in Latin America, 1980 to 2000", Comparative political studies, 37(8), pp. 909-940.

Franklin, M., C. Eijk, D. Evans, M. Fotos, W. Hirczy de Mino, M. Marsh and B. Wessels (2004): Voter Turnout and the Dynamics of Electoral Competition in Established Democracies since 1945, Cambridge, Cambridge University Press.

García, D. L. L. (2019): "Cuba: su propia democracia. Una aproximación al tema/Cuba: its own Democracy. An Approach to the Subject", Estudios del Desarrollo Social: Cuba y América Latina, 7(1), pp. 39-53.

Hobolt, C. B. (2009): Europe in question: referendums on European integration, New York, Oxford University Press.

Hughes, C. (2012): Liberal democracy as the end of history: Fukuyama and postmodern challenges, New York, Routledge, Routledge innovations in political theory, 40.

Inglehart, R. (1997): Modernization and postmodernization: cultural, economic, and political change in 43 societies, Princeton, Princeton University Press.

Jackman, R. W. (1987): "Political Institutions and Voter Turnout in the Industrial Democracies", American Political Science Review, 81(2), pp. 405-424.

Jurado Nacional de Elecciones (2019): Lima: Jurado Nacional de Elecciones. Available at: http://portal.jne.gob.pe/portal [Accessed: 7. 12. 2019]

Justicia Electoral, República del Paraguay (2019): Asunción: Justicia Electoral, República del Paraguay. Available at: http://tsje. gov.py/ [Accessed: 7. 12. 2019]

Karp, J. A. and S. A. Banducci (2007): "Party mobilization and political participation in new and old democracies", Party Politics, 13(2), pp. 217-234.

Kostadinova, T. and T. J. Power (2007): "Does Democratization Depress Participation? Voter Turnout in the Latin American and Eastern European Transitional Democracies", Political Research Quarterly, 60(3), pp. 363-377.

Kouba, K. (2016): "Party institutionalization and the removal of presidential term limits in Latin America", Revista de Ciencia Política, 36(2), pp.433-457.

Kouba, K., J. Novák and M. Strnad (2020): "Explaining voter turnout in local elections: a global comparative perspective", Contemporary Politics, 27(1), pp. 58-78.

Latinobarómetro, C. (2018): Informe Latinobarómetro 2018, Santiago de Chile. Available at: www.latinobarometro.org [Accessed: 14. 12. 2019]

LeDuc, L. (2007): “Opinion formation and change in referendum campaigns”, in C. H. de Vreese, ed., The Dynamics of Referendum Campaigns: an international perspective, Palgrave Macmillan, London, pp. 21-44. 
Lijphart, A. (1997): “Unequal Participation: Democracy’s Unsolved Dilemma Presidential Address, American Political Science Association, 1996", American Political Science Review, 91, pp. 1-14.

Lissidini, A. (2011): Democracia directa en Latinoamerica. Entre la delegación y la participación, CLACSO, Colección Becas de Investigación.

Nevitte, N., A. Blais, E. Gidengril and R. Nadeau (2009): "Socioeconomic Status and Nonvoting: A Cross-National Comparative Analysis", Klingemann, H. and I. Macallister, eds, The Comparative Study of Electoral Systems, Cambridge, Cambridge University Press, pp. 88-105.

Nohlen, D. ed. (2005a): Elections in the Americas: A Data Handbook: Volume 1 North America, Central America, and the Caribbean (Vol. 1), Oxford University Press on Demand.

Nohlen, D. ed. (2005b): Elections in the Americas: A Data Handbook: Volume 2 South America (Vol. 2), Oxford University Press on Demand.

O'Donnell, G. and P. C. Schmitter (1986): Transitions from authoritarian rule: Tentative conclusions about uncertain democracies, Baltimore, Johns Hopkins University Press.

O’Donnell, G. A. (1996): "Illusions about consolidation”, Journal of democracy, 7(2), pp. 34-51.

Oficina Nacional de Procesos Electorales (2019): Lima: Oficina Nacional de Procesos Electorales. Available at: https://www. web.onpe.gob.pe/ [Accessed: 7. 12. 2019]

Órgano Electoral Plurinacional (2019): La Paz: Órgano Electoral Plurinacional. Available at: https://www.oep.org.bo/ [Accessed: 8. 12. 2019]

Pacek, A. C., G. Pop-Eleches and J. A. Tucker (2009): "Disenchanted or discerning: Voter turnout in post-communist countries", The Journal of Politics, 71(2), pp. 473-491.

Palop-García, P. and L. Pedroza (2019): "Passed, regulated, or applied? The different stages of emigrant enfranchisement in Latin America and the Caribbean", Democratization, 26(3), pp. 401-421.

Pemstein, D., K. L. Marquardt, E. Tzelgov, Y. Wang, J. Medzihorsky, J. Krusell, F. Miri and J. von Römer (2019): The V-Dem Measurement Model: Latent Variable Analysis for Cross-National and Cross-Temporal Expert-Coded Data, V-Dem Working Paper No. 21. 4th edition, University of Gothenburg, Varieties of Democracy Institute.

Podestà, F. (2002): "Recent developments in quantitative comparative methodology: The case of pooled time series cross-section analysis", DSS Papers Soc, 3(2), pp. 5-44.

Polity IV. (2018): Polity IV Annual Time-Series, 1800-2018. Available at: https://www.systemicpeace.org/inscrdata.html [Accessed: 15. 12. 2019]

Polity IV. (2019): Polity IV Project: Dataset Users' Manual, Available at: http://www.systemicpeace.org/inscr/p4manualv2018. pdf [Accessed: 16. 12. 2019]

Powell, G. B. (1982): Contemporary democracies, Harvard University Press.

Putnam, R. D. (2000): Bowling alone: the collapse and revival of american community, New York, Simon \& Schuster.

Qvortrup, M. (2014): Referendums around the World: The Continued Growth of Direct Democracy, Basingstoke, Palgrave Macmillan.

Radcliff, B. (1992): “The welfare state, turnout, and the economy: A comparative analysis", American Political Science Review, 86, pp. 444-454.

Rallings, C., M. Thrasher and G. Borisyk (2003): "Seasonal Factors, Voter Fatigue, and the Costs of Voting", Electoral Studies, 22, pp. 65-79.

Reif, K., H. Schmitt and P. Norris (1997): “Second $\square$ order elections”, European Journal of Political Research, 31(1 $\square 2)$, pp. 109-124.

Renwick, A. (2017): "Referendums", in K. Arzheimer, Evans, J., and Lewis-Beck, M., eds., The Sage Handbook of Electoral Behaviour, London, Sage, pp. 433-458.

Riker, W. H. and P. C. Ordeshook (1968): “A Theory of the Calculus of Voting”, American Political Science Review, 62(1), pp. 25-42.

Rivero, M. I. (2019): IACHR Concerned about Cuba's New Constitution and its Implementation. OAS. Available at: https://www. oas.org/en/iachr/media_center/PReleases/2019/058.asp [Accessed: 7. 12. 2019]

Ruth-Lovell, S.P., Y. Welp and L. Whitehead (2017): Let the people rule? Direct democracy in the twenty-first century, ECPR press.

Santos Villarreal, G. M. (2009): Referéndum Constitucional de Bolivia 2009, Centro de Documentación, Información y Análisis, Dirección de Servicios de Investigación y Análisis, Subdirección de Política Exterior, Cámara de Diputados.

Servicio Electoral de Chile (2019): Santiago de Chile: Servicio Electoral de Chile. Available at: https://www.servel.cl/ [Accessed: 7. 12. 2019]

Smith, M. A. (2001): "The contingent effects of ballot initiatives and candidate races on turnout", American Journal of Political Science, pp.700-706.

Soberg, M. and T. P. Tangeras (2007): "Voter turnout in small referendums", Electoral Studies 26(2), pp. 445-459.

Stockemer, D., B. LaMontagne and L. Scruggs (2013): "Bribes and ballots: The impact of corruption on voter turnout in democracies", International political science review, 34(1), pp. 74-90.

Stockemer, D. (2017): "What affects voter turnout? A review article/meta-analysis of aggregate research", Government and Opposition, 52(4), pp. 698-722.

Torres Forero, C. A. (2006): De las aulas a las urnas: la Universidad del Rosario, la séptima papeleta y la constituyente de 1991, Bogotá, Editorial Universidad del Rosario.

Tribunal Calificador de Elecciones de Chile (2019): Santiago de Chile: Tribunal Calificador de Elecciones de Chile. Available at: http://www.tribunalcalificador.cl/ [Accessed: 7. 12. 2019]

Tribunal Contencioso Electoral del Ecuador (2019): Quito: Gobierno Nacional de la República de Ecuador. Available at: http:// www.tce.gob.ec/ [Accessed: 14. 12. 2019] 
Tribunal Electoral (2019): Panamá: Tribunal Electoral. Available at: http://www.tribunal-electoral.gob.pa/ [Accessed: 7.12. 2019]

Tribunal Superior Eleitoral (2019): Brasilia/DF: Tribunal Superior Eleitoral. Available at: http://www.tse.jus.br/ [Accessed: 8. 12. 2019]

Tribunal Supremo de Elecciones (2019): San José: Tribunal Supremo de Elecciones. Available at: http://www.tse.go.cr/ [Accessed: 15. 12. 2019]

Tribunal Supremo Electoral (2019): Ciudad de Guatemala: Tribunal Supremo Electoral. Available at: http://www.tse.org.gt/ [Accessed: 14. 12. 2019]

Valenzuela, J. S. (1995): The origins and transformations of the Chilean party system, Helen Kellogg Institute for International Studies.

Verba, S. and G. Almond (1963): The civic culture. Political Attitudes and Democracy in Five Nations, Princeton university press. World Bank (2019): GDP per capita (current US\$), World Development Indicators, The World Bank Group. Available at: https:// data.worldbank.org/indicator/NY.GDP.PCAP.CD [Accessed: 7. 12. 2019] 